\title{
Comparative Characterization and Amylase Activity Assessment of Certain Garden Bacterial Isolates
}

\author{
Munia Islam ${ }^{a}$ and Tamanna Zerin ${ }^{a^{*}}$
}

\begin{abstract}
Background: Microorganisms are the most important sources of enzymes because of their stability and reduced price in production. The enzyme, amylase has a wide spectrum of application in biotechnology including food, fermentation, textile and laundry, paper and pulp industries. As the use of amylase is increased, it is necessary to search for a new source to produce amylase with better productivity in continuous practice. Method: In our present investigation, amylase producing bacteria were screened by starch hydrolysis test as bacteria are more potent in amylase production than other microorganisms. The bacteria were identified by Bergey's manual of systematic bacteriology. Enzyme assay and optimization of enzyme activity were performed by the 3,5-dinitrosalicylic acid method. Results: A total of eight bacterial isolates were identified with starch degrading capabilities and they were presumptively placed in the genus, Bacillus due to their characteristic features. All the isolates have potential for amylase activity. At any temperature $\left(25^{\circ} \mathrm{C}, 35^{\circ} \mathrm{C}, 45^{\circ} \mathrm{C}, 50^{\circ} \mathrm{C}\right.$ and $\left.55^{\circ} \mathrm{C}\right), \mathrm{pH}(6,7$, 8 ) and starch concentrations $(0.5 \%, 1 \%$ and $1.5 \%)$, the highest amylase activity was observed by isolate $1 \mathrm{~A}$ followed by isolate $2 \mathrm{C}, 1 \mathrm{~B}, 3 \mathrm{~A}, 4 \mathrm{~B}, 3 \mathrm{~B}, 4 \mathrm{~A}$, and $4 \mathrm{C}$. Optimum conditions for the highest amylase activity in our laboratory for isolate $1 \mathrm{~A}$ was $35^{\circ} \mathrm{C}(4.105 \mathrm{U} / \mathrm{ml}), \mathrm{pH} 6$
\end{abstract}

Significance | Screening of soil Bacillus spp. for amylolytic activity

\section{${ }^{*}$ Correspondence: Dr. Tamanna Zerin Assistant Professor, Department of Microbiology Stamford University Bangladesh 51 Siddeswari Road, Dhaka-1217, Bangladesh. Tel: $+88028355626,+88028355596$ ext. 478 Cell: +8801715042811 \\ E-mail: tzerin1983 @gmail.com}

Edited by Md. Fakruddin Murad, PhD, IRCMS, Kumamoto University, Japan. And accepted by the Editorial Board July 15, 2019 (received for review June 3, 2019)
$(3.343 \mathrm{U} / \mathrm{ml})$ and $1.5 \%$ starch concentration $(4.381 \mathrm{U} / \mathrm{ml})$. Conclusion: Our study reveals that the isolates, collected from garden soil, are good amylase producers and they could be exploited in different industries in optimized conditions.

Keywords: Amylase, Enzyme activity, DNS, Soil, Optimization.

Abbreviations: DNS, 3,5 dinitrosalicylic acid; MR, methyl red; VP, vogesproskauer; GPB, glucose phosphate broth; MIU, motility indole urea.

\section{Introduction}

Starch, a glucose polymer, is the main constituent of human diet that is physically and chemically treated industrially to generate starch hydrolysates, glucose syrups, fructose, maltodextrin derivatives or cyclodextrins for various food industries. For various industrial applications, starch is hydrolyzed to smaller oligosaccharide by the enzyme, amylase (de Souza and de Oliveira Magalhães, 2010). Amylases occupy nearly $25 \%$ of the world enzyme market has a huge application in a range of industries as food, detergent, paper, textile, and fermentation (Rajagopalan and Krishnan, 2008; Reddy et al., 2003). The extent of biotechnology has widened the potential use of amylase in clinical, medicinal, analytical chemistry, brewing and distillation industries as well (Gupta et al., 2003; Kandra, 2003; Pandey et al., 2000). Amylase can be produced by different sources like animals, plants, and microbes (Kathiresan and Manivannan, 2006). Out of approximately, 100 industrially important enzymes, around one half is acquired from yeast and fungi, and around one third from bacteria, and the rest are collected from plants (4\%) and animals (8\%) (Patel, 2015). However, microbial sources of amylase are considered beneficial due to cost-effectiveness, consistency as well as, less space and time (Gopinath SC et al., 2017; Rao et al., 1998). Thermo-stability is a desirable property of most of the industrial enzy-

\footnotetext{
Author Affiliation:

a Department of Microbiology, Stamford University Bangladesh, 51, Siddeswari Road, Dhaka-1217, Bangladesh.

Please cite this article:

Islam M, Zerin T (2019). Comparative Characterization and Assessment of Amylase Activity of Certain Garden Bacterial Isolates, 2(1), 091-097.

2209-2153/৫ 2018 MICROBIAL BIOACTIVES, a publication of Eman Research Ltd, Australia. This is an open access article under the CC BY-NC-ND license. (http:///creativecommons.org/licenses/by-nc-nd/4.0/).
(http://microbialbioactives.emanresearch.org).
} 
mes and in that case, thermostable bacterial $\alpha$-amlylase enzyme from Bacillus subtilis, $B$. stearothermophilus, $B$. licheniformis and $B$. amyloliquefaciens are produced industrially for various applications (Prakash and Jaiswal, 2010). Furthermore, in some harsh industrial processes where high salt concentration could resist enzymatic conversion in most cases, halotolerant amylases from halophilic bacteria can be a choice that is also considered as thermotolerant. Thermotolerant amylase producing bacteria includes Chromohalobacter sp. (Prakash et al., 2009), Halobacillus sp. (Amoozegar et al., 2003), Haloarcula hispanica (Hutcheon et al., 2005), Halomonas meridiana (Coronado et al., 2000), and Bacillus dipsosauri (Deutch, 2002).

Due to the increased usage of amylase enzyme, it is fundamental to search for new indigenous amylase producing microbes with better productivity in a continuous process and optimize the process to improve their activity. Researchers are using different sources to isolate efficient amylase producing microbes (Aiba et al., 1983; Tonkova et al., 1993; Kathiresan and Manivannan, 2006, Mishra and Behera, 2008). Soil is a habitat where a diverse array of microflora and fauna reside and improve soil fertility by the biochemical transformation of complex organic materials to easily accessible nutrients for plants (Patel, 2015). In our study, we chose soil from the garden as it is very rich in nutrients. Following the primary screening, we isolated and characterized amylase producing bacteria and compared their amylolytic activity by optimizing temperature, $\mathrm{pH}$ and substrate concentrations.

\section{Methods}

\section{Sample collection and processing}

Soil samples were collected in a sterile beaker using sterile spatula at a depth of 2-3 cm from rich garden soil in Siddeshwari campus of Stamford University Bangladesh, Dhaka, Bangladesh. One gram of soil sample was dispensed into $99 \mathrm{ml}$ of sterile normal saline and homogenized as described previously (Cappuccino and Sherman, 1996). One $\mathrm{ml}$ of homogenized soil sample was transferred into $9 \mathrm{ml}$ sterile normal saline and serial dilution was carried out up to $10^{-6}$ dilution

\section{Isolation and screening of amylase producing bacteria}

Bacterial isolates were isolated and screened for amylase production by starch hydrolysis test on starch agar media as described previously (Bala et al., 2013; Kaur et al., 2012). Serially diluted bacterial cultures $(100 \mu \mathrm{l})$ were spread on nutrient agar media and incubated at $37^{\circ} \mathrm{C}$ for $24 \mathrm{~h}$. Subsequently, isolated colonies were streaked on starch agar media containing starch as the only carbon source for starch hydrolysis test to detect their amylolytic activity. The plates were incubated at $37^{\circ} \mathrm{C}$ for $24-48 \mathrm{~h}$. Following incubation, plates were flooded with Gram's iodine (Gram's iodine- $250 \mathrm{mg}$ iodine crystals added to $2.5 \mathrm{~g}$ potassium iodide solution, and $125 \mathrm{ml}$ of water, kept at room temperature) to identify the zone of clearance around the colony. Deep blue color around the growth indicates a negative result that is no amylolytic activity where the zone of clearance produced by amylase producers. The pure cultures showing clear zones were subcultured at regular interval and maintained on to nutrient agar slants at $4^{\circ} \mathrm{C}$.

\section{Identification of amylase producing bacteria}

Isolated amylase producing bacteria were presumptively identified by Gram staining, spore staining, motility test, cultural and biochemical characteristics using the taxonomic scheme of Bergey's manual of determinative bacteriology. The biochemical tests included methyl red, voges-proskauer, citrate utilization, indole production, $\mathrm{H}_{2} \mathrm{~S}$ production, motility, gelatine hydrolysis, sugar hydrolysis, oxidase, catalase and carbohydrate fermentation.

\section{Preparation of cell free enzyme}

To extract amylase enzyme, a loopful of pure culture was inoculated in production media containing starch $(10 \mathrm{~g} / \mathrm{l})$, peptone $(5 \mathrm{~g} / \mathrm{l})$, $\left(\mathrm{NH}_{4}\right)_{2} \mathrm{SO}_{4}(2 \mathrm{~g} / \mathrm{l}), \mathrm{KH}_{2} \mathrm{PO}_{4}(1 \mathrm{~g} / \mathrm{l}), \mathrm{K}_{2} \mathrm{HPO}_{4}(2 \mathrm{~g} / \mathrm{l}), \mathrm{MgCL}_{2}(0.01 \mathrm{~g} / \mathrm{l})$ at $\mathrm{pH} 7$ and incubated at $37^{\circ} \mathrm{C}$ in a shaking water bath at $120 \mathrm{rpm}$ for 24 h (Vaidya and Rathore, 2015). Following incubation, $10 \mathrm{ml}$ of $24 \mathrm{~h}$ old culture was centrifuged at $5000 \mathrm{rpm}$ for $15 \mathrm{~min}$. Cells were discarded and the supernatant was decanted for the crude enzyme that was used for the optimization of assay condition for amylase activity.

\section{Amylase assay}

Amylase activity was assayed by employing 3,5 dinitrosalicylic acid (DNS) method as described (Bernfeld, 1955) with few modifications. In brief, $1 \%$ starch solution was prepared freshly by dissolving $1 \mathrm{~g}$ of soluble starch in $100 \mathrm{ml}$ of $0.02 \mathrm{M}$ sodium phosphate buffer $(\mathrm{pH}, 7)$. To prepare the assay condition, $1 \mathrm{ml}$ of $1 \%$ starch solution and $0.5 \mathrm{ml}$ of crude enzyme extract were incubated at $50^{\circ} \mathrm{C}$ for $30 \mathrm{~min}$. The assay was stopped by adding $3 \mathrm{ml}$ of DNS reagent and heated the solution in a boiling water bath for $10 \mathrm{~min}$. Then, with running tap water the solution was cooled. The solution volume was brought up to $10 \mathrm{ml}$ by distilled $\mathrm{H}_{2} \mathrm{O}$ and the absorbance was recorded using a spectrophotometer. A blank was always prepared without the enzyme. Enzyme activity was measured by preparing a standard graph with known concentrations of the standard (glucose), and plotted. Here, one unit $(\mathrm{U} / \mathrm{ml})$ of amylase activity is defined as the amount of amylase required to catalyze $1 \mu \mathrm{mol}$ of reducing sugar (glucose) from starch per minute under the assay condition.

\section{Characterization of the crude amylase enzyme}

To determine the effect of different parameters enzyme assay was performed at different temperature, $\mathrm{pH}$ and starch concentrations.

\section{Effect of temperature}

A range of temperature as $25^{\circ} \mathrm{C}, 35^{\circ} \mathrm{C}, 45^{\circ} \mathrm{C}, 50^{\circ} \mathrm{C}$, and $55^{\circ} \mathrm{C}$ was used to measure the optimal temperature for enzyme assay, otherwise, all the procedure are the same for enzyme assay as previously mentioned. 
Table 1l Microscopic observation of the amylase producing bacterial isolates

\begin{tabular}{|c|c|c|c|c|}
\hline \multirow{3}{*}{$\begin{array}{l}\text { Bacterial } \\
\text { isolates }\end{array}$} & \multicolumn{4}{|c|}{ Microscopic observation } \\
\hline & Shape & Arrangement & Gram & Spore \\
\hline & & & Reaction & Staining \\
\hline $1 \mathrm{~A}$ & short rod & single & $+\mathrm{ve}$ & -ve \\
\hline 1B & long rod & single, chain & $+\mathrm{ve}$ & $+\mathrm{ve}$ \\
\hline $2 \mathrm{C}$ & long rod & single, chain & $+\mathrm{ve}$ & + ve \\
\hline $3 \mathrm{~A}$ & long rod & single, chain & +ve & $+\mathrm{ve}$ \\
\hline $3 B$ & short rod & single, chain & +ve & -ve \\
\hline $4 \mathrm{~A}$ & short rod & single & +ve & $+\mathrm{ve}$ \\
\hline $4 B$ & long rod & single, chain & $+\mathrm{ve}$ & +ve \\
\hline $4 C$ & short rod & single & +ve & -ve \\
\hline
\end{tabular}

\section{Effect of $\mathbf{p H}$}

Optimum $\mathrm{pH}$ for enzyme activity was determined by performing the enzyme assay in three different $\mathrm{pH}$ conditions as 6,7 and 8 at their optimum temperature determined before. All the experiments for enzyme assay were performed as previously mentioned.

\section{Effect of starch concentration}

Three different starch concentrations as $0.5 \%, 1 \%$, and $1.5 \%$ were used as a substrate to obtain optimum substrate concentration for enzyme assay. Optimum temperature and $\mathrm{pH}$ condition as determined previously were maintained to determine the effect of different starch concentrations on enzyme activity. The enzyme activity was performed as previously mentioned.

\section{Results}

\section{Isolation and characterization of amylase producing bacteria}

Amylase producing bacteria were screened by starch hydrolysis test. A total of 8 bacterial isolates as $1 \mathrm{~A}, 1 \mathrm{~B}, 2 \mathrm{C}, 3 \mathrm{~A}, 3 \mathrm{~B}, 4 \mathrm{~A}, 4 \mathrm{~B}$ and $4 \mathrm{C}$ were found to exhibit a zone of clearance with iodine solution.

All those isolates were subjected to characterization by morphological (Table 1), cultural (Table 2) and biochemical tests (Table 3) and found to belong to the genus, Bacillus. A representative picture for endospore former (a) and clear zone for starch hydrolysis test (b) by isolate $1 \mathrm{~B}$ is showed in Figure 1.

\section{Effect of different parameter on enzyme activity}

The amylolytic activity was performed by DNS method with glucose standard curve that was presented in Supplementary Figure 1. The effect of temperature on amylase activity of eight bacterial isolates was observed and showed in Figure 2. Among them, five isolates (1B, $2 \mathrm{C}, 3 \mathrm{~A}, 3 \mathrm{~B}$ and $4 \mathrm{~A}$ ) showed the highest activity at $50^{\circ} \mathrm{C}$, whereas, the rest three isolates $(1 \mathrm{~A}, 4 \mathrm{~B}$ and $4 \mathrm{C})$ at $35^{\circ} \mathrm{C}$. The highest amylase activity was observed by the isolate $1 \mathrm{~A}(4.105 \mathrm{U} / \mathrm{ml})$, followed by isolates $2 \mathrm{C}, 1 \mathrm{~B}, 3 \mathrm{~A}, 4 \mathrm{~B}, 3 \mathrm{~B}, 4 \mathrm{~A}$ and $4 \mathrm{C}$.

The consequence of $\mathrm{pH}$ condition also affects amylase activity that was presented in Figure 3. Amylase activity was observed under three different $\mathrm{pH}$ conditions with their optimum temperature as determined previously where 6 isolates $(1 \mathrm{~A}, 1 \mathrm{~B}, 2 \mathrm{C}, 3 \mathrm{~A}, 4 \mathrm{~A}$, and $4 \mathrm{~B})$ showed the highest activity at $\mathrm{pH} 6$. Others (3B and $4 \mathrm{C}$ ) showed the highest activity at $\mathrm{pH}$ 7. As previously observed, the highest amylase activity was observed by the isolate $1 \mathrm{~A}(3.875 \mathrm{U} / \mathrm{ml})$ followed by isolates $2 \mathrm{C}, 1 \mathrm{~B}, 3 \mathrm{~A}, 4 \mathrm{~B}, 3 \mathrm{~B}, 4 \mathrm{~A}$ and $4 \mathrm{C}$.

Amylase activity was performed using 3 different starch concentrations as $0.5 \%, 1 \%$ and $1.5 \%$ by maintaining optimum temperature and $\mathrm{pH}$ conditions obtained from the previous result. All the isolates showed the highest activity at the highest starch concentration (Figure 4). The highest activity for the enzyme, amylase by the isolates followed the similar pattern as mentioned in temperature and $\mathrm{pH}$ optimization experiments.

With the use of optimal temperature, $\mathrm{pH}$ and starch concentrations, the activity was greatly improved for all the isolates. All the isolates showed a temperature-, $\mathrm{pH}$ - and substrate concentration-dependent increase in activity, while it reached its optimal condition, the activity decreased afterward.

\section{Discussion}

Starch degrading bacteria collected from rich in starchy material may have a greater potential to produce amylase enzyme (Mishra and behera, 2008). In our study, we collected soil from garden containing various types of flowering and fruit plants. We believed that the soil would be a good choice to isolate amylase producing bacteria as they constantly exposed to soil containing enormous amount of starchy material from those plants. We were able to isolate eight starch degrading bacteria from primary screening by starch hydrolysis test using iodine solution. Following morphological, cultural and biochemical analysis, they were presumptively found to belong to the genus, Bacillus. This finding is in agreement with others' work who found that Bacillus is the predominant amylase producing bacteria from different sources as soil from bakery waste (Bala et al., 2013), soil from the potato field (Kaur et al., 2012), soil from the garden (Patel, 2015), soil receiving kitchen wastes (Mishra and Behera, 2008). We found the highest amylolytic activity that was $4.381 \mathrm{U} / \mathrm{ml}$ by the isolate, $1 \mathrm{~A}$ at $35^{\circ} \mathrm{C}, \mathrm{pH} 6$ and $1.5 \%$ starch concentration which is higher than other Bacillus spp. isolated from different sources (Islam et al., 2016; Kaur et al., 2012).

We observed the highest enzyme activity at $35^{\circ} \mathrm{C}$ by the isolates $1 \mathrm{~A}$ (4.105 U/ml), 4B $(0.887 \mathrm{U} / \mathrm{ml}), 4 \mathrm{C}(0.639 \mathrm{U} / \mathrm{ml})$, and at $50^{\circ} \mathrm{C}$ by $1 \mathrm{~B}$ $(2.428 \mathrm{U} / \mathrm{ml}), 2 \mathrm{C}(2.956 \mathrm{U} / \mathrm{ml}), 3 \mathrm{~A}(1.625 \mathrm{U} / \mathrm{ml}), 3 \mathrm{~B}(0.734 \mathrm{U} / \mathrm{ml})$, and $4 \mathrm{~A}(0.685 \mathrm{U} / \mathrm{ml})$. It was reported that the thermal stability of some wheat a-amylases was stable up to $50^{\circ} \mathrm{C}$ and some upto $40^{\circ} \mathrm{C}$ following incubation (Mohamed et al., 2009). Whereas, a-amylases isolated from microorganisms had a wider range of stability that suits 

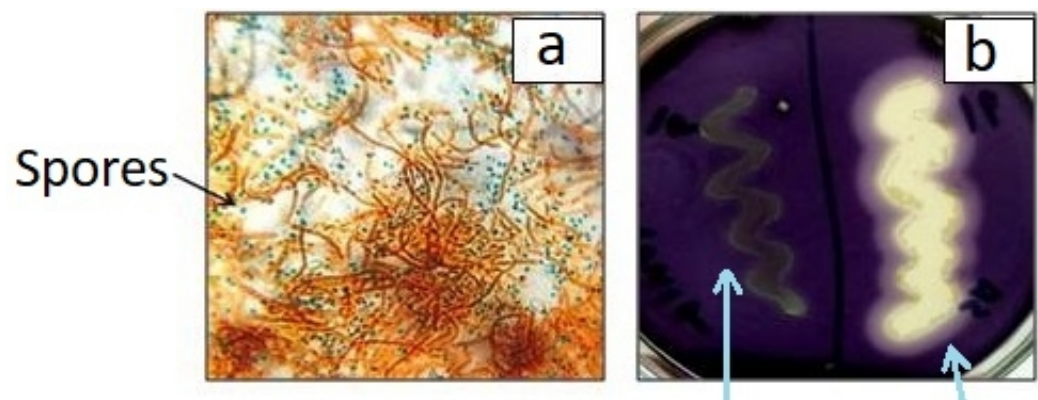

Negative Starch Control hydrolysis
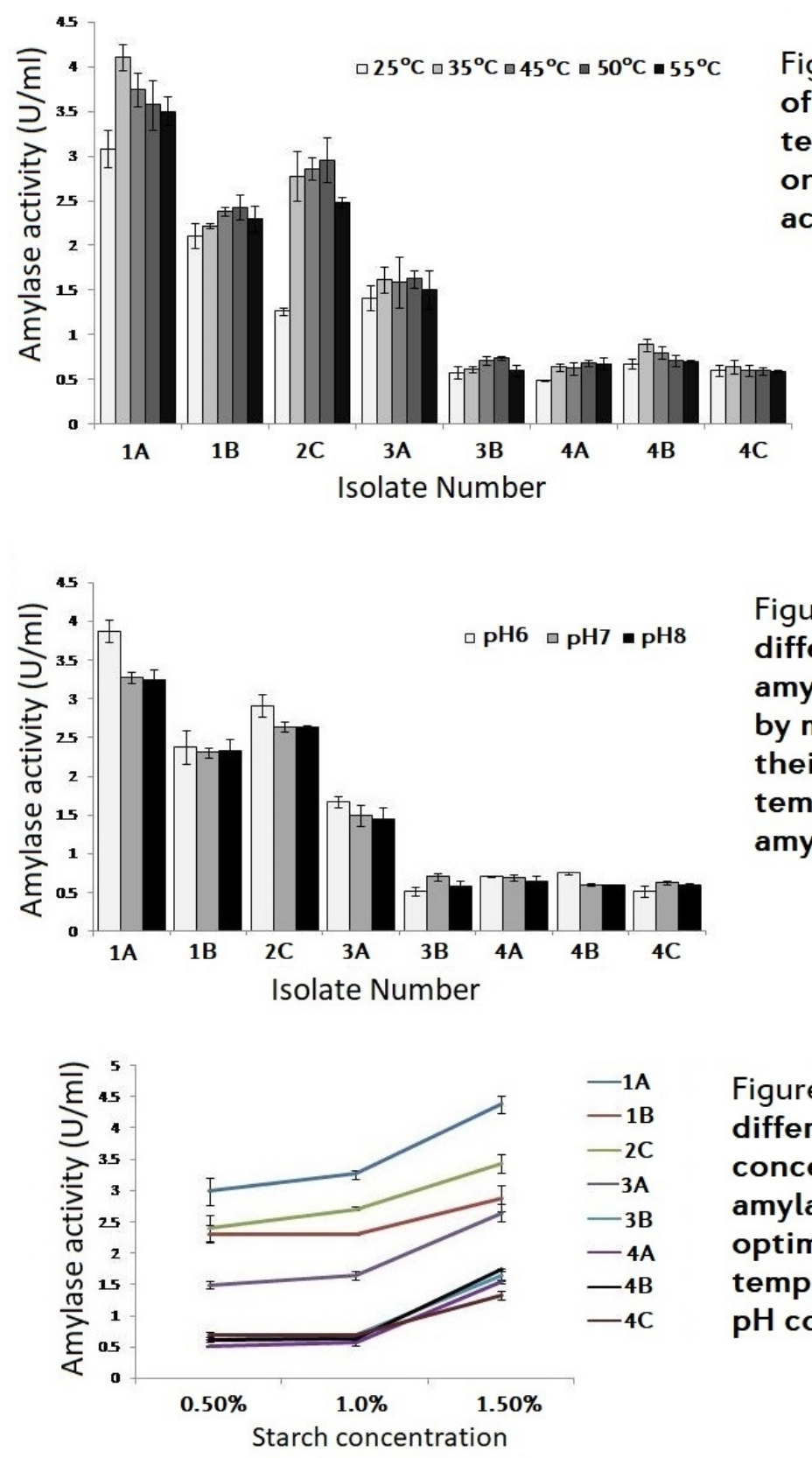

Figure 2I Effect of different temperature on amylase activity.
Figure 4l Effect of different starch concentrations on amylase activity at optimal temperature and $\mathrm{pH}$ conditions.
Figure 1l A representative picture of endospore former by isolate $1 \mathrm{~B}$ with malachite green staining, and the spores were marked as green 1 (a). Clear zone by starch hydrolysis test was observed by the isolate, $1 \mathrm{~A}$ at the right side of the plate, and a negative control is presented at the left side of the plate that showed no hydrolysis 1(b).
Figure 31 Effect of different $\mathrm{pH}$ on amylase activity by maintaining their optimal temperature for amylase activity. 
Table 2I Colony characteristics of the amylase producing bacterial isolates on nutrient agar media.

\begin{tabular}{|c|c|c|c|c|c|c|c|c|}
\hline Characteristics & $1 \mathrm{~A}$ & 1B & $2 \mathrm{C}$ & $3 A$ & $3 B$ & $4 \mathrm{~A}$ & $4 B$ & $4 \mathrm{C}$ \\
\hline Size & Medium & Large & Large & Medium & Medium & Small & Large & Small \\
\hline Shape & Irregular & Irregular & Round & Round & Irregular & Round & Round & Round \\
\hline Margin & Serrate & Lobate & Entire & Entire & Undulate & Entire & Undulate & Entire \\
\hline Elevation & Flat & Flat & Umbonate & Umbonate & Flat & Flat & Flat & Flat \\
\hline Consistency & Moist & Butyrous & Butyrous & Butyrous & Butyrous & Moist & Butyrous & Moist \\
\hline Texture & Rough & Smooth & Smooth & Smooth & Smooth & Rough & Smooth & Smooth \\
\hline Opacity & Opaque & Opaque & Opaque & Opaque & Opaque & Opaque & Opaque & Opaque \\
\hline Odor & Earthy & Earthy & Earthy & Earthy & Earthy & Earthy & Earthy & Earthy \\
\hline Pigmentation & White & $\begin{array}{l}\text { Creamy } \\
\text { white }\end{array}$ & Creamy white & Creamy white & Yellow & Creamy white & White & White \\
\hline
\end{tabular}

Table 3I Biochemical characteristics of the amylase producing isolates.

\begin{tabular}{|c|c|c|c|c|c|c|c|c|c|}
\hline \multirow{2}{*}{ Tests } & \multirow{2}{*}{ Media } & \multicolumn{8}{|c|}{ Observation } \\
\hline & & $1 \mathrm{~A}$ & 1B & $2 \mathrm{C}$ & $3 A$ & 3B & $4 \mathrm{~A}$ & $4 \mathrm{~B}$ & $4 \mathrm{C}$ \\
\hline Starch hydrolysis & Starch agar plate & +++ & +++ & +++ & ++ & + & + & + & + \\
\hline MR test & GPB broth & - & - & + & - & - & - & + & - \\
\hline VP test & GPB broth & - & - & - & - & - & + & - & + \\
\hline Citrate utilization & Simmons citrate agar slant & + & - & - & + & - & + & - & - \\
\hline Indole production & $1 \%$ peptone & - & - & - & - & - & - & - & - \\
\hline $\mathrm{H}_{2} \mathrm{~S}$ production & $2 \%$ peptone & - & - & - & - & - & - & - & - \\
\hline Motility test & MIU media & - & + & + & + & - & + & + & + \\
\hline Gelatin hydrolysis & Gelatin media & - & - & - & - & - & - & - & - \\
\hline Sugar hydrolysis & Triple sugar iron agar slant & $\mathrm{K} / \mathrm{A}$ & $\mathrm{A} / \mathrm{A}$ & $\mathrm{A} / \mathrm{A}$ & $\mathrm{A} / \mathrm{A}$ & $\mathrm{K} / \mathrm{A}$ & $\mathrm{A} / \mathrm{A}$ & $\mathrm{K} / \mathrm{A}$ & $\mathrm{K} / \mathrm{A}$ \\
\hline Oxidase & Nutrient agar & - & + & + & + & + & + & + & + \\
\hline Catalase & Nutrient agar & + & + & + & + & + & + & + & + \\
\hline Carbohydrate fermentation & Glucose & + & + & + & + & + & + & + & + \\
\hline Carbohydrate fermentation & Fructose & - & - & + & + & - & - & + & - \\
\hline Carbohydrate fermentation & Maltose & - & + & + & + & - & - & + & + \\
\hline Carbohydrate fermentation & Lactose & - & + & - & + & + & - & + & + \\
\hline Carbohydrate fermentation & Dextrose & - & - & + & + & - & - & + & + \\
\hline Carbohydrate fermentation & Sucrose & + & - & + & + & + & + & + & + \\
\hline
\end{tabular}

them in various industrial applications comparative to those isolated from plants and animals (Tanyildizi et al., 2005). We maintained growth temperature for all those isolates at a fixed temperature that is $37^{\circ} \mathrm{C}$.

The maximum amylase activity in our study was found at $\mathrm{pH}$ 6-7. None of the enzymes isolated from bacterial isolates showed the highest activity at $\mathrm{pH} 8$. This data correlates with another study where it was observed that most of the starch degrading bacteria had a $\mathrm{pH}$ range 6-7 for both growth and enzyme activity (Gupta et al., 2003) although, amylase enzyme from thermostable bacteria revealed the highest activity at pH 8 (Behal et al., 2006).

The activity of the enzyme was influenced by reaction conditions as temperature, $\mathrm{pH}$, substrate concentration, etc. Among several parameters, we only chose those three parameters to optimize amylase activity as they are considered very crucial for the activity of the enzyme, and they are mostly selected for optimizing enzyme activity by other resear chers (Megahati et al., 2017; Dutta et al., 2016). Our data showed the greatest activity with the highest starch concentration that was $1.5 \%$ although it was necessary to do experiment to determine enzyme activity using the concentration of 
starch more than $1.5 \%$. The previous study also showed that increased starch concentration from $0.15 \%$ to $2 \%$ enhanced amylase activity (Mishra and Behera, 2008).

\section{Conclusion}

Amylase is one of the most widely used enzymes that are required in various industries. We isolated starch degrading bacteria from rich garden soil and tried to characterize enzyme assay conditions as temperature, $\mathrm{pH}$ and starch concentration. With optimal assay condition, the activity was greatly improved. Our data can be useful for further improvement of assay conditions and thereby, increasing enzyme activity.

\section{Acknowledgement}

We thank the Department of Microbiology, Stamford University Bangladesh for logistic support throughout our study.

\section{Author Contribution}

TZ designed the study, Both TZ and MI analyzed the data, prepared the manuscript and revised the data. All the authors approved the manuscript.

\section{Competing financial interests}

There is no competing financial interest.

\section{References}

Aiba, S., Kitai, K., \& Imanaka, T. (1983). Cloning and Expression of Thermostable $\alpha$-Amylase Gene from Bacillus stearothermophilus in Bacillus stearothermophilus and Bacillus subtilis. Applied and Environmental Microbiology, 46(5), 1059-1065.

Amoozegar, M.A., Malekzadeh. F., \& Malik, K.A. (2003). Production of amylase by newly isolated moderate halophile, Halobacillus sp. strain MA-2. Journal of Microbiological Methods, 52(3), 353-9

https://doi.org/10.1016/S0167-7012(02)00191-4

Bala, J.D., Abioye, O.P., Auta, H.S., Damisa, D., Adabara, N.U., \& Tuggen, T.O. (2013) Screening of soil microorganisms for amylase production. BTAIJ, 7(1), 22-27.

Behal, A., Singh, J., Sharma, M.K., Puri, P., \& Batra, N. (2006). Characterization of Alkaline $\alpha$-Amylase from Bacillus sp. AB 04. International journal of agriculture and biology, 8(1), 8083.

Bernfeld, P. (1955). Amylase $\alpha$ and $\beta$. Methods in Enzymology, 1, 149-158. https://doi.org/10.1016/0076-6879(55)01021-5

Cappuccino, J.G. and Sherman, N. (1996) Microbiology: A Laboratory Manual. 4th Edition, p. cm. Includes index. ISBN 0-8053-0573-4.

Coronado, M., Vargas, C., Hofemeister, J., Ventosa, A., \& Nieto, J.J. (2000). Production and biochemical characterization of an alpha-amylase from the moderate halophile Halomonas meridiana. FEMS Microbiology Letters, 183(1), 67-71. https://doi.org/10.1111/j.15746968.2000.tb08935.x

https://doi.org/10.1016/S0378-1097(99)00628-X

De Souza, P.M., \& de Oliveira Magalhães, P. (2010). Application of microbial $\alpha$-amylase in industry: a review. Brazilian Journal of Microbiology, 41(4), 850-861. https://doi.org/10.1590/S1517-83822010000400004 PMid:24031565 PMCid:PMC3769773

Deutch, C.E. (2002). Characterization of a salt-tolerant extracellular a-amylase from Bacillus dipsosauri. Letters in Applied Microbiology, 35(1), 78-84. https://doi.org/10.1046/j.1472 $765 \times .2002 .01142 . x$

PMid:12081555

Dutta, P., Deb, A., \& Sukanta Majumdar, S. (2016). Optimization of the Medium for the Production of Extracellular Amylase by the Pseudomonas stutzeri ISL B5 Isolated from Municipal Solid Waste. International Journal of Microbiology, 2016, 4950743. https://doi.org/10.1155/2016/4950743

PMid:28096816 PMCid:PMC5206451

Gopinath SC, Anbu P, Arshad MK, Lakshmipriya T, Voon CH, Hashim U \& Chinni SV. (2017). Biotechnological Processes in Microbial Amylase Production. Biomed Research International, 2017, 1272193. https://doi.org/10.1155/2017/1272193 PMid:28280725 PMCid:PMC5322433

Gupta, R., Gigras, P., Mohapatra, H., Goswami, V.K., \& Chauhan, B. (2003). Microbial $\alpha-$ amylases: a biotechnological perspective. Process Biochemistry, 38(11), 1599-1616. https://doi.org/10.1016/S0032-9592(03)00053-0

Hutcheon, G.W., Vasisht, N., \& Bolhuis, A. (2005). Characterisation of a highly stable alphaamylase from the halophilic archaeon Haloarcula hispanica. Extremophiles, 9(6), 487-95. https://doi.org/10.1007/s00792-005-0471-2 PMid:16075161

Islam, M.R., Mondol, OK, Md. Rahman, M.S., Billah, M.M., Rahman, M.S., \& Zohora, U.S. (2016). Screening of $\alpha$-amylase producing bacteria from tannery wastes of Hazaribag, Bangladesh. Jahangirnagar University Journal of Biological Sciences, 5(2), 1-10. https://doi.org/10.3329/jujbs.v5i2.32511

Kandra, L. (2003). $\alpha$-Amylases of medical and industrial importance. Journal of Molecular Structure (Theochem), 666-667, 487-498

https://doi.org/10.1016/j.theochem.2003.08.073

Kathiresan, K., \& Manivannan, S. (2006). a Amylase production by Penicillium fellutanum isolated from mangrove rhizosphere soil. African Journal of Biotechnology, 5(10), 829-832.

Kaur, A., Kaur, M., Samyal, M.L., \& Ahmed, Z. (2012). Isolation, characterization and identification of bacterial strain producing amylase. Journal of Microbiology and Biotechnology Research, 2(4), 573-579. 
Mishra, S., \& Behera, N. (2008). Amylase activity of a starch degrading bacteria isolated from soil receiving kitchen wastes. African Journal of Biotechnology, 7(18), 3326-3331.

Megahati R.R.P., Mansyurdin, Agustien A., \& Tjong, D.H. (2017). Optimization of Bacteria Amylase Activity from Bacillus licheniformis Strain SEM11. International Journal of Current Microbiolology and Applied Sciences, 6(11), 2938-2946.

https://doi.org/10.20546/ijcmas.2017.611.345

Mohamed, S.A., Al-Malki, A.L., \& Kumosani, T.A. (2009). Partial purification and characterization of five $\alpha$-amylases from a wheat local variety (Balady) during germination. Australian Journal of Basic and Applied Sciences, 3(3), 1740-1748.

Pandey, A., Nigam, P., Soccol, C.R., Soccol, V.T., Singh, D., \& Mohan, R. (2000). Advances in Microbial Amylases. Biotechnology and Applied Biochemistry, 31(Pt 2), 135-152. https://doi.org/10.1042/BA19990073

PMid:10744959

Patel, G. (2015). Isolation and Characterization of Starch Degrading Bacteria from Garden Soil, Ganpat University, Gujarat, India. Indian Journal of Microbiology Research, 2(2),111114.

Prakash, B., Vidyasagar, M., Madhukumar, M.S., Muralikrishna, G., \& Sreeramulu, K. (2009). Production, purification, and characterization of two extremely halotolerant, thermostable, and alkali-stable $\alpha$-amylases from Chromohalobacter sp. TVSP 101. Process Biochemistry, 44(2), 210-215. https://doi.org/10.1016/j.procbio.2008.10.013

Prakash, O., \& Jaiswal, N. (2010). alpha-Amylase: an ideal representative of thermostable enzymes. Applied Biochemistry and Biotechnology, 160(8), 2401-14. https://doi.org/10.1007/s12010-009-8735-4

PMid: 19763902

Rajagopalan, G. \& Krishnan, C. (2008). Alpha-amylase production from catabolite derepressed Bacillus subtilis KCC103 utilizing sugarcane bagasse hydrolysate. Bioresource Technology, 99(8), 3044-3050.

https://doi.org/10.1016/j.biortech.2007.06.001 PMid:17644331

Rao, M., Tankasale, A., Ghatge, M., \& Desphande, V. (1998). Molecular and biotechnological aspects of microbial proteases. Microbiology and Molecular Biology Reviews, 62(3), 597-634.

Reddy, N.S., Nimmagadda, A., \& Sambasiva Rao, K.R.S. (2003). An overview of the microbial $\alpha$-amylase family. African Journal of Biotechnology, 2(12), 645-648. https://doi.org/10.5897/AJB2003.000-1119

Tanyildizi, M.S., Ozer, D., \& Elibol, M. (2005). Optimization of $\alpha$-amylase production by Bacillus sp. using response surface methodology. Process Biochemistry, 40(7), 2291-2296. https://doi.org/10.1016/j.procbio.2004.06.018
Bacillus licheniformis produced in high yields from glucose. Process Biochemistry, 28(8), 539-542.

https://doi.org/10.1016/0032-9592(93)85015-8

Vaidya, S., \& Rathore, P. (2015). Isolation, Screening and Characterization of amylase producing bacteria from soil of potato dump sites from different regions of Madhya Pradesh. Conference article from International conference on recent trends in agriculture, veterinary and life sciences published in Life Science International research journal, ISBN 978-9384124-26-7.
Submit your next manuscript to Microbial Bioactives published by EMAN Research

- Convenient online submission

- Thorough peer review

- No space constraints or color figure charges

- Immediate publication on acceptance

- Inclusion in Australian National Libraray and Google Scholar

- Both Open (80-100\% subsidized APC by ER) \& non-open access option

Submit your manuscript at https://publishing.emanresearch.org 